\title{
UNIVERSITY OF WISCONSIN RADIOCARBON DATES XVII
}

\author{
MARGARET M BENDER, DAVID A BAERREIS, \\ and REID A BRYSON \\ Center for Climatic Research, 1225 W Dayton Street, \\ University of Wisconsin-Madison
}

Procedures and equipment have been described in previous date lists. Except as otherwise indicated, wood, charcoal and peat samples are pretreated with dilute $\mathrm{NaOH}$ and dilute $\mathrm{H}_{3} \mathrm{PO}_{4}$ before conversion to the counting gas methane; marls and lake cores are treated with acid only. Very calcareous materials are treated with $\mathrm{HCl}$ instead of $\mathrm{H}_{3} \mathrm{PO}_{4}$.

The dates reported have been calculated using 5568 as the half-life of ${ }^{14} \mathrm{C}$ with 1950 as the reference year. The standard deviation quoted includes only the $1 \sigma$ of the counting statistics of background, sample, and standard counts. Background methane is prepared from anthracite, standard methane from NBS oxalic acid. The activities of the dated samples for which $\delta^{13} \mathrm{C}$ values are listed have been corrected to correspond to a $\delta^{13} \mathrm{C}$ value of $-25 \%$.

Sample descriptions are based on information supplied by those who submitted samples.

\section{ACKNOWLEDGMENTS}

This research is supported by the National Science Foundation under Grant No. ATM74-23041. We thank the Chemistry Department for the use of the RMS 6-60 mass spectrometer. We also wish to thank Raymond Steventon and Arden Berge for technical assistance.

\section{ARCHAEOLOGIC SAMPLES}

\section{A. North Dakota}

\section{Anderson Mound site (32RM236)}

Charred wood (either Pinus or Juniperus spp) from wood-lined burial pit, 50 to $75 \mathrm{~cm}$ below ground level, in early Plains Woodland burial mound excavated 1959-1960 by Elden Johnson, Univ Minnesota, in Ransom Co $\left(46^{\circ} 31^{\prime} 20^{\prime \prime} \mathrm{N}, 97^{\circ} 26^{\prime} 15^{\prime \prime} \mathrm{W}\right)$. At least 2 burials recovered from mound, assoc with cord-roughened pottery, projectile points, scrapers and lithic debitage. Mound may be related to Sonata complex (Hewes, 1949; Neuman, 1975). Subm by Rain Vehik, Univ Oklahoma, Norman.

\section{WIS-1016. Anderson Mound site (32RM236)}

Acid treatment only. Sample counted only once.

WIS-1021. Anderson Mound site (32RM236)

Sample treated with base and acid.

$$
\begin{array}{r}
\mathbf{4 7 0} \pm \mathbf{7 5} \\
\delta^{13} \mathrm{C}=-26.0 \% 0
\end{array}
$$

$\delta^{13} C=-25.9 \%$ 


\section{B. South Dakota}

\section{WIS-1074. Crow Creek site (39BF11)}

$$
\begin{array}{r}
\mathbf{6 1 0} \pm \mathbf{5 5} \\
\delta^{13} C=-26.8 \% \%
\end{array}
$$

Charcoal from outer fortification ditch, lower level of Bone Bed "B", mass deposit of human bone, Crow Creek site, Buffalo Co, $\left(43^{\circ} 59^{\prime} 50^{\prime \prime} \mathrm{N}\right.$, $\left.99^{\circ} 19^{\prime} 54^{\prime \prime} \mathrm{W}\right)$. Material dates end of occupation of site when massacre of at least 500 people occurred. Event took place in middle or end of Initial Coalescent component (Kivett \& Jensen, 1976). Sample coll Oct 1978 and subm by T E Emerson, Univ S Dakota, Vermillion.

II. GEOLOGIC SAMPLES

\section{A. Kansas}

WIS-1030. Max Brown Gravel Quarry

$$
\begin{array}{r}
2395 \pm 65 \\
\delta^{1 s} C=-27.4 \%
\end{array}
$$

Quercus sp (id verified by $\mathrm{R}$ Miller, Forest Products Laboratory, Madison, Wisconsin) buried within river terrace gravel at depth of $12 \mathrm{~m}$ in Max Brown Gravel Quarry, Bonner Springs, Johnson Co $\left(39^{\circ} 3^{\prime} \mathrm{N}\right.$, $94^{\circ} 5^{\prime}$ W). Coll October, 1978, by W C Johnson, Univ Kansas, Lawrence. Specimen dates lowermost (youngest) terrace level within lower Kansas $\mathbf{R}$ system; identifies period of intensified river activity thought to be in response to climatic change during Holocene. Sample dated to attempt to document synchroneity of Kansas R system and those of upper Midwest, specifically Kickapoo R system (Johnson, 1978).

\section{B. Minnesota}

\section{Horseshoe Lake series}

Core HD taken with $2.5 \mathrm{~cm}$ diam Livingstone piston sampler in March 1974 from Horseshoe Lake, Isanti Co $\left(45^{\circ} 27^{\prime} \mathrm{N}, 93^{\circ} 2^{\prime} \mathrm{W}\right)$. Core from area of thickest sediments in lake basin, depth to glacial drift $1110 \mathrm{~cm}$. Depths measured from water surface, depth of water at core site $117 \mathrm{~cm}$. Horseshoe Lake is on Anoka Sand Plain in E central Minnesota in tension zone between conifer forest and deciduous forest, near S limit of continuous range of Pinus strobus and Betula Papyfera. Pollen diagram from core is near completion. Coll and subm by E J Cushing, Univ Minnesota, Minneapolis. Late glacial portion of pollen stratigraphy was dated by Stuiver, Y-1973 -1978 (R, 1969, v 11, p 574).

\section{WIS-1025. Horseshoe Lake site}

$$
\begin{array}{r}
\mathbf{9 1 0} \pm \mathbf{7 0} \\
\delta^{13} \mathrm{C}=-18.9 \% \text { \% }
\end{array}
$$

Algal copropel with fine plant detritus, scattered Najas seeds, from 207 to $217 \mathrm{~cm}$ segment of core. Increase of birch pollen at $200 \mathrm{~cm}$ and of white pine at $185 \mathrm{~cm}$ suggests invasion of oak forest by these sp near lake; southward migration of sp may have resulted from cooling of climate. Sample counted only once. 
WIS-1028. Horseshoe Lake site

$$
\begin{array}{r}
\mathbf{2 2 9 0} \pm \mathbf{6 5} \\
\delta^{13} C=-19.9 \% \text { o }
\end{array}
$$

Non-calcareous algal copropel with fine plant detritus from 347 to $352 \mathrm{~cm}$ segment of core. Pollen assemblage between 200 and $450 \mathrm{~cm}$ in core is thought to represent closed vegetation of Quercus macrocarpa and $Q$ ellipsoidalis grubs, sprouts and scattered trees. An increase in Larix pollen in this zone may mark immigration of tamarack to marshes in area.

WIS-1024. Horseshoe Lake site

$$
\begin{array}{r}
\mathbf{3 7 0 5} \pm \mathbf{7 0} \\
\delta^{18} C=-21.0 \% \text { o }
\end{array}
$$

Non-calcareous algal copropel with fine plant detritus from 487 to $492 \mathrm{~cm}$ section. At this level in core oak pollen increases (above 25\%), birch and alder increase and grass, Ambrosia, and Artemisia decrease. May mark invasion of prairie by Quercus shrubland and forest and of open marsh by shrubs from decrease in frequency of fire.

\section{WIS-1027. Horseshoe Lake site}

$4650 \pm 75$

$$
\delta^{13} \mathrm{C}=-20.7 \%
$$

Non-calcareous humified copropel from 607 to $612 \mathrm{~cm}$ section. Quercus pollen increases at this level in core suggesting invasion of open prairie and marsh by oaks in local habitats protected from fire.

WIS-1026. Horseshoe Lake site

$$
\begin{array}{r}
\mathbf{6 1 6 5} \pm \mathbf{8 0} \\
\delta^{13} \mathrm{C}=-18.6 \% \circ
\end{array}
$$

Non-calcareous algal copropel with fine plant detritus from 787 to $792 \mathrm{~cm}$ sect. Pollen assemblage between 500 and $980 \mathrm{~cm}$ is dominated by non-arboreal pollen. At ca $780 \mathrm{~cm}$ dominant herb type changes from Artemisia to Gramineae. At $810 \mathrm{~cm}$ sharp but brief increase of Pinus strobus pollen probably marks its initial immigration to this area. Similar event is known from nearby Cedar Bog Lake where it was dated at 7880 ВP (Y-1197) (R, 1963, v 5, p 323).

\section{WIS-1029. Horseshoe Lake site}

$$
\begin{array}{r}
\mathbf{7 5 5 0} \pm \mathbf{9 0} \\
\delta^{13} \mathrm{C}=-18.0 \% 0
\end{array}
$$

Moderately calcareous algal copropel 947 to $952 \mathrm{~cm} \mathrm{sec}$ of core. Boundary between Pinus pteridium pollen assemblage zone and QuercusGramineae-Artemisia assemblage zone is at $980 \mathrm{~cm}$. In adjacent core, correlative pollen-stratigraphic event was dated at 8510 BP, Y-1973 (R, 1969, v 11, p 574).

\section{French Lake site}

Core, 5.1cm diam, coll Feb 1978 from French Lake, McLeod Co, $\left(44^{\circ} 57^{\prime} \mathrm{N}, 94^{\circ} 25^{\prime} \mathrm{W}\right.$ ) by E C Grimm; subm by H E Wright, Jr. Pollen analysis of core is in preparation for study of vegetation history along prairie-forest border in S central Minnesota. Site was only a few $\mathrm{km}$ from prairie-forest border at time of settlement by European man. 


\section{WIS-1011. French Lake site}

$$
\begin{array}{r}
390 \pm \mathbf{6 0} \\
\delta^{13} C=-30.9 \%
\end{array}
$$

Detritus gyttja 60 to $70 \mathrm{~cm}$ below sediment surface immediately below Ambrosia rise at beginning of cultural horizon in sediment. Lake is located on calcareous till.

\section{WIS-1012. French Lake site}

$$
\begin{array}{r}
\mathbf{8 1 0} \pm \mathbf{6 0} \\
\delta^{13} C=-26.8 \% \text { 。 }
\end{array}
$$

Lake sediment 720 to $730 \mathrm{~cm}$ below water surface, sediment surface at $5.76 \mathrm{~m}$. Sample marks increase in Carya and Juglans cinerea pollen, may mark development of Big Woods at this site.

\section{WIS-1009. French Lake site}

$$
\begin{array}{r}
\mathbf{2 6 1 5} \pm \mathbf{6 5} \\
\delta^{13} C=-22.6 \% \text { \% }
\end{array}
$$

Silty gyttja 945 to $955 \mathrm{~cm}$ below water surface. Sample marks dramatic increase in Quercus pollen percentages and forest invasion of prairie.

\section{WIS-1013. French Lake site}

$$
\begin{array}{r}
\mathbf{3 7 8 5} \pm \mathbf{7 0} \\
\delta^{13} C=-24.6 \% 0
\end{array}
$$

Silty gyttja 1150 to $1160 \mathrm{~cm}$ below water surface. Pollen assemblage at this depth typical of that from prairie.

\section{Wolsfeld Lake site}

Lake core, $12 \mathrm{~m}$ in length, $5 \mathrm{~cm}$ diam, coll Dec 1977 by E C Grimm, Univ Minnesota, from Wolsfeld Lake, Hennepin Co, Minnesota $\left(45^{\circ}\right.$ $00^{\prime} \mathrm{N}, 93^{\circ} 34^{\prime} \mathrm{W}$ ). Pollen analysis of core to be used in study of vegetational history of prairie-forest border in S central Minnesota. Depths are from water surface, sediment surface was $6.48 \mathrm{~m}$ deep. Subm by E C Grimm.

WIS-1002. Wolsfeld Lake site

$$
\begin{array}{r}
\mathbf{6 3 0} \pm \mathbf{5 5} \\
\delta^{13} C=-28.5 \% 0
\end{array}
$$

Lake sediment, gyttja, 7.10 to $7.20 \mathrm{~m}$ deep, immediately below stratigraphic marker that should date ca AD 1860. Sample dated to check on influence of ancient carbon in sediment of lake.

WIS-1003. Wolsfeld Lake site

$$
\delta^{13} C=-31.4 \% 0
$$

Lake sediment 7.80 to $7.90 \mathrm{~m}$ deep. Sample marks beginning of succession from oak dominated vegetation to mesic deciduous forest.

WIS-1005. Wolsfeld Lake site

$$
\begin{array}{r}
\mathbf{2 7 9 0} \pm \mathbf{6 5} \\
\delta^{13} C=-29.4 \%
\end{array}
$$

Lake sediment 9.70 to $9.80 \mathrm{~m}$ deep. Sample marks an increase in grass pollen percentage. 
WIS-1006. Wolsfeld Lake site

Lake sediment 10.60 to $10.70 \mathrm{~m}$ deep. Sample marks significant decrease in organic matter on layer of silt.

WIS-1007. Wolsfeld Lake site

$4030 \pm 75$

Lake sediment 11.30 to $11.40 \mathrm{r}$ deep. Sample marks increase in Quercus pollen percentage which presumably indicates forest invasion of prairie.

WIS-1008. Wolsfeld Lake sile

$$
\begin{array}{r}
5640 \pm 70 \\
\delta^{13} C=-25.1 \% \text { o }
\end{array}
$$

Lake sediment 13.40 to $13.50 \mathrm{~m}$ deep. Sample marks lowest stratigraphic position used in study.

WIS-1033. Wolsfeld Lake site

$$
\delta^{1 s} C=-29.8 \% \text { o }
$$

Lake sediment 7.45 to $7.55 \mathrm{~m}$ deep. Sample marks change from oak dominated vegetation to mesic deciduous forest, marks significant change in pollen spectra and dates above and below sample are in very different sediment types. Lake sediment dates require correction because of ancient carbon and correction may be different in these 2 sediment types.

WIS-1034. Wolsfeld Lake site

$$
\begin{array}{r}
12,060 \pm 125 \\
\delta^{13} C=-27.2 \%
\end{array}
$$

Trash layer at base of lake sediment core 1770 to $1778 \mathrm{~cm}$ deep. Glacial till immediately below; sample contained wood, needles, and roots of Picea and Larix.

\section{WIS-1037. Chasebrook 14 site}

$$
\begin{array}{r}
3950 \pm \mathbf{8 0} \\
\delta^{13} C=-28.6 \% 。
\end{array}
$$

Peat coll Oct 1978 by H E Wright, Univ Minnesota, Minneapolis from site in Koochiching Co $\left(48^{\circ} 20^{\prime} \mathrm{N}, 94^{\circ} 23^{\prime} \mathrm{W}\right)$. Sample from 320 to $352 \mathrm{~cm}$ below surface at base of peat on top of till. Dates beginning of peat growth at this locality in Red Lake Peatland (Griffin, 1977). Subm by $\mathrm{H}$ E Wright.

\section{WIS-1035. Chasebrook 17 site}

$$
\begin{array}{r}
1950 \pm 65 \\
\delta^{13} C=-26.9 \% o
\end{array}
$$

Peat coll Oct 1978 by H E Wright, from site in Beltrami Co $\left(48^{\circ} 17^{\prime}\right.$ $\mathrm{N}, 95^{\circ} 01^{\prime} \mathrm{W}$ ). Sample from 150 to $155 \mathrm{~cm}$ below surface at base of peat on top of sand. Dates beginning of peat growth.

\section{Brandreth Lake Inlet site}

$$
\text { C. New York }
$$

Eight cores sampled Sept 1978 from bog $2 \mathrm{~km}$ up Brandreth Lake Inlet in Adirondack Mts, Hamilton Co, New York $\left(44^{\circ} 55^{\prime} \mathrm{N}, 74^{\circ} 41^{\prime} \mathrm{W}\right)$. Samples dated to establish deposition rates in paleoecological/paleoclimatological study of peat bog. Pollen. analysis of cores is underway. Coll and subm by J T Overpeck and R R. Kautz, Hamilton Coll, New York. 
WIS-1050. Brandreth Lake Inlet site

$10,360 \pm 100$

$\delta^{13} C=-31.3 \%$

Peat, 997 to $1023 \mathrm{~cm}$ interval of $10.52 \mathrm{~m}$ core through homogeneous peat and into underlying lake bottom sediments.

WIS-1052. Brandreth Lake Inlet site

$$
\begin{array}{r}
\mathbf{3 2 4 5} \pm \mathbf{6 5} \\
\delta^{13} C=-28.3 \% \text {. }
\end{array}
$$

Peat, 231 to $249 \mathrm{~cm}$ interval of $10.52 \mathrm{~m}$ core.

WIS-1051. Brandreth Lake Inlet site

$$
\begin{array}{r}
\mathbf{7 8 8 0} \pm \mathbf{1 0 0} \\
\delta^{13} \mathrm{C}=-28.6 \%
\end{array}
$$

Slightly micaceous peat, 231 to $249 \mathrm{~cm}$ interval of $298 \mathrm{~cm}$ core through homogeneous peats and into underlying sediments.

\section{Wisconsin}

\section{South Waubesa Wetlands site}

Core samples obtained Nov 1978 from South Waubesa marsh, Dane Co $\left(42^{\circ} 59^{\prime} \mathrm{N}, 89^{\circ} 21^{\prime} \mathrm{W}\right)$ by $\mathrm{T} \mathrm{K}$ Kratz and R M Friedman, Univ Wisconsin-Madison. Subm by G B DeWitt, Univ Wisconsin-Madison. Peat samples from selected portions of marsh dated to determine rate of lake edge wetlands formation (Friedman \& DeWitt, 1978). Dates on samples coll earlier have been reported ( $R, 1979$, v 21, p 128-129).

\section{WIS-1036. South Waubesa Wetlands site}

$$
\begin{array}{r}
\mathbf{6 2 0} \pm \mathbf{6 5} \\
\delta^{13} \mathrm{C}=-30.3 \% 0
\end{array}
$$

Band peat, $12 \mathrm{~cm}$, immediately above fibrous to lake sedimentary peat transition $1.05 \mathrm{~m}$ below surface.

\section{WIS-1038. South Waubesa Wetlands site}

$$
\begin{array}{r}
1615 \pm 65 \\
\delta^{13} C=-32.0 \%
\end{array}
$$

Band fibrous peat, $12 \mathrm{~cm}$ immediately above fibrous to lake sedimentary peat transition, $1.45 \mathrm{~m}$ below surface.

WIS-1039. South Waubesa Wetlands site

$$
\begin{array}{r}
1505 \pm 65 \\
\delta^{13} C=-28.4 \%
\end{array}
$$

Band fibrous peat, $12 \mathrm{~cm}$, immediately above transition zone, $1.25 \mathrm{~m}$ below surface.

WIS-1040. South Waubesa Wetlands site $\mathbf{3 2 1 5} \pm \mathbf{5 5}$ $\delta^{13} \mathrm{C}=-25.7 \%$

Band fibrous peat, $12 \mathrm{~cm}$, immediately above transition zone, $1.55 \mathrm{~m}$ below surface.

WIS-1041. South Waubesa Wetlands site

$$
\begin{array}{r}
\mathbf{6 8 4 0} \pm \mathbf{9 0} \\
\delta^{13} C=-30.1 \%
\end{array}
$$

Band fibrous peat, $12 \mathrm{~cm}$, immediately above transition zone, $1.55 \mathrm{~m}$ below surface. 
WIS-1042. South Waubesa Wetlands site

Peat 10 to $15 \mathrm{~cm}$ below surface, level at which Ambrosia pollen increased. Dates beginning of European settlement in area.

WIS-1043. South Waubesa Wetlands site $\quad 1760 \pm 70$

$\delta^{13} C=-29.8 \%$

Peat 76 to $81 \mathrm{~cm}$ below surface, above transition lake sediment to peat. Increase in total pine pollen and decrease in oak and hickory pollen occur above this level.

WIS-1045. Lima Bog site

$$
\begin{array}{r}
\mathbf{8 0 7 0} \pm \mathbf{1 0 0} \\
\delta^{13} \mathrm{C}=-27.5 \% \text { o }
\end{array}
$$

Calcareous organic gyttja, 990 to $1000 \mathrm{~cm} \mathrm{sec} \mathrm{of} \mathrm{core} \mathrm{from} \mathrm{Lima} \mathrm{Bog,}$ Rock Co $\left(42^{\circ} 48^{\prime} \mathrm{N}, 88^{\circ} 51^{\prime} \mathrm{W}\right)$. Sample from base of core into early postglacial sediments. Oak and elm pollen decreasing, Gramineae, Artemisia, and Ambrosia-type pollen percentages increasing at this horizon. One 3-day count. Coll and subm by $\mathrm{K}$ Van Zant, Earlham Coll, Richmond, Indiana.

\section{Devil's Lake site}

Core, $6.03 \mathrm{~m}$ coll Feb 1978 by L J Maher, Jr, Univ Wisconsin-Madison from NW part of Devil's Lake, Sauk Co $\left(43^{\circ} 25^{\prime} \mathrm{N}, 89^{\circ} 44^{\prime} \mathrm{W}\right)$. Core to be used in pollen influx study. Sample depths are below sediment surface, water depth $11.75 \mathrm{~m}$. Second core coll March 1979, water depth $12.1 \mathrm{~m}$. Subm by L J Maher, Jr.

WIS-993. Devil's Lake site $245 \pm 55$

Organic lake sediment from 16 to $21 \mathrm{~cm}$ below sediment surface.

WIS-994. Devil's Lake site

Gyttja from 138 to $144 \mathrm{~cm}$ interval.

\section{W IS-995. Devil's Lake site}

Gyttja from 164 to $169 \mathrm{~cm}$ below sediment surface.

WIS-996. Devil's Lake site

Gyttja from 263 to $267 \mathrm{~cm}$ below sediment surface.

WIS-997. Devil's Lake site

Gyttja from 334 to $338 \mathrm{~cm}$ below sediment surface.

WIS-998. Devil's Lake site

Gyttja from 395 to $399 \mathrm{~cm}$ below sediment surface.

$$
\begin{array}{r}
\mathbf{2 0 5 5} \pm \mathbf{6 5} \\
\delta^{13} C=-25.4 \%
\end{array}
$$

$$
\begin{array}{r}
\mathbf{2 4 3 0} \pm \mathbf{6 5} \\
\delta^{13} C=-23.0 \% \text { o }
\end{array}
$$

$$
\begin{array}{r}
4105 \pm \mathbf{6 5} \\
\delta^{13} C=-24.8 \% \circ
\end{array}
$$

$5245 \pm 65$ $\delta^{13} C=-27.5 \%$ o

$$
6920 \pm 75
$$

$\delta^{13} C=-28.0 \%$ 


\section{WIS-999. Devil's Lake site}

Gyttja from 455 to $459 \mathrm{~cm}$ below sediment surface.

WIS-1000. Devil's Lake site

Gyttja from 514 to $518 \mathrm{~cm}$ interval of core.

WIS-1001. Devil's Lake site

Silty gyttja 541 to $547 \mathrm{~cm}$ below surface.

WIS-1004. Devil's Lake site

Silty gyttja 599 to $603 \mathrm{~cm}$ below surface.

WIS-1073. Devil's Lake site

$$
\begin{array}{r}
\mathbf{8 6 4 0} \pm \mathbf{8 5} \\
\delta^{13} C=-26.6 \% \text { o }
\end{array}
$$

$10,080 \pm 100$ $\delta^{13} \mathrm{C}=-29.7 \%$

$10,620 \pm 105$ $\delta^{13} C=-29.2 \%$

$12,880 \pm 125$

$\delta^{13} C=-31.3 \%$

$12,260 \pm 115$

$\left[\delta^{13} \mathrm{C}=-31.0 \%\right.$ o

Gyttja, $4 \mathrm{~cm}$ interval, from $6 \mathrm{~m}$ depth of second core. Sample is lowermost organic sediment lying over laminated clay. $\delta^{13} \mathrm{C}$ value assumed from WIS-1075.

WIS-1075. Devil's Lake site

$12,520 \pm 160$

$\delta^{13} \mathrm{C}=-31.0 \%$

Lake sediment and laminated olive black clay, $8 \mathrm{~cm}$ interval, from $6 \mathrm{~m}$ depth of 2nd core. Sample is uppermost portion of laminated inorganic clay unit under organic lake sediments. One 3-day count.

\section{Platte River}

Site is part of river reach currently undergoing in-depth studies of late Quaternary fluvial deposits. Samples coll Sept and Dec, 1978 by J C Knox, Univ Wisconsin-Madison, from Grant Co $\left(42^{\circ} 56^{\prime} \mathrm{N}, 90^{\circ} 30^{\prime} \mathrm{W}\right)$. Subm by J C Knox. Approx base of Woodfordian age fluvial deposit at this site also recently dated $(22,270 \pm 650$, IGS-558).

WIS-1029. Platte River site base.

Wood (Fraxinus) $180 \mathrm{~cm}$ deep in silty sand near contact with gravel

WIS-1072. Platte River site

$\mathbf{3 8 0} \pm \mathbf{5 0}$

Wood (Ulmus rubra) $140 \mathrm{~cm}$ deep in organic rich sandy silt near contact with gravel base. Above dates, with other Holocene radiocarbon dates for SW Wisconsin valley alluvium $(\mathrm{R}, 1971$, v 13, p 481; $R, 1973$, v 15, p 622-623; R, 1975, v 17, p 133; R, 1976, v 18, p 135-137; R, 1977, $\mathrm{v}$ 19, $\mathrm{p}$ 134-135) reveal that valley bottom alluviation by coarse gravels was relatively modest in response to climatic changes of Holocene in comparison to effects of agricultural land use in past $150 \mathrm{yr}$.

WIS-1023. Pine River site

$9520 \pm 95$

Stump wood (Picea) coll April 1975 by J C Knox from drainage ditch tributary to Fancy Creek, Pine R system, Richland Co, $\left(42^{\circ} 24^{\prime} \mathrm{N}\right.$, 
$\left.90^{\circ} 24^{\prime} \mathrm{W}\right)$. Sample 180 to $190 \mathrm{~cm}$ deep in dense stump horizon; represents termination of spruce growth at site. Silt unit directly above stump zone probably correlates with climate shift to warmer and drier conditions during early Mid-Holocene. Silt unit $(80 \mathrm{~cm})$ in turn buried by $1 \mathrm{~m}$ of peat thought to be assoc with return to cooler/wetter conditions of late Holocene.

\section{Brush Creek, Wisconsin}

Samples coll Sept, Oct and Nov, 1978, from stream deposits in Brush Creek, Monroe Co, by P F McDowell, Univ Wisconsin-Madison. Dates on previous samples from Brush Creek have been reported ( $\mathrm{R}, 1975$, v 17, p 133; R, 1976, v 18, p 135). Brush Cireek is site of intensive study of relationship between fluvial activity and climatic change during Holocene (Johnson, 1976; Knox, 1972).

WIS-1022. Brush Creek site

$4410 \pm 75$

Wood from $2.1 \mathrm{~m}$ below surface of silty alluvial deposits and immediately above stream laid gravels in stream bank exposure on Kuder Farm $\left(43^{\circ} 44^{\prime}\right.$ N, $\left.90^{\circ} 42^{\prime} \mathrm{W}\right)$. Date fluvial deposition related to adjacent peat deposit on valley floor. Fluvial activity and peat growth resulted from shift to cooler/wetter climatic conditions.

WIS-1018. Brush Creek site

$9060 \pm 95$

Wood, Fraxinus sp, $2.5 \mathrm{~m}$ below surface of silty alluvial deposits and immediately above stream-laid gravels from right bank of Upper Brush Creek on Helmuth Farm $\left(43^{\circ} 44^{\prime} \mathrm{N}, 90^{\circ} 41^{\prime} \mathrm{W}\right)$. Sample found $8 \mathrm{~m}$ downstream from WIS-674, dated at $5055 \pm 65$ (R, 1975, v 17, p 133). Sample dates deposition of early Holocene valley fill assoc with fluvial adjustments to post-glacial climatic change. Early Holocene deposits were extensively eroded some time before 5055 BP.

WIS-1044. Brush Creek site

$4540 \pm 70$

Wood fragments $2.2 \mathrm{~m}$ below surface of alluvial deposits on Hansen Farm, Monroe Co $\left(43^{\circ} 44^{\prime} \mathrm{N}, 90^{\circ} 40^{\prime} \mathrm{W}\right)$. Sample taken from drill hole $170 \mathrm{~m}$ N of WIS-757 (2940 $\pm 60 ; \mathrm{R}, 1976$, v 18, p 135). Dates indicate late Holocene shift in channel of Brush Creek and extent of erosion of early Holocene alluvial deposits.

WIS-1046. Brush Creek site

$7810 \pm 95$

Wood, 2.5m below surface of alluvial deposits from right bank of Brush Creek on Feitner Farm $\left(43^{\circ} 44^{\prime} \mathrm{N}, 90^{\circ} 38^{\prime} \mathrm{W}\right)$. Dates episode of fluvial adjustment to mid-Holocene shift to drier climatic and vegetation conditions. With WIS-1018 (9060 \pm 95$)$ and several younger dates from Brush Creek, sample dates soil chronosequence developed in alluvial deposits of early, mid-, and late Holocene ages.

WIS-1071. Brush Creek site $5145 \pm 65$

Wood $2.3 \mathrm{~m}$ below surface of alluvial deposits from left bank of Upper Brush Creek on Peter Leis pasture, Monroe Co $\left(43^{\circ} 44^{\prime} \mathrm{N}, 90^{\circ} 42^{\prime} \mathrm{W}\right)$. 
With WIS-813 (5045 $\pm 70:$ R, 1977, v 19, p 135) and WIS-1022 (4410 \pm 75) above dates period of intensive fluvial adjustment in response to climatic change to cooler and wetter conditions and helps to explain origin of valley floor peat deposits.

\section{Stewart's Dark Lake site}

$10.45 \mathrm{~m}$ core coll from Stewart's Dark Lake, Rusk Co $\left(45^{\circ} 18^{\prime} \mathrm{N}\right.$, $\left.91^{\circ} 27^{\prime} \mathrm{W}\right)$ March 1978. Because of possibility that core top was $20 \mathrm{~cm}$ below sediment surface, 2nd core was sampled Nov 1978 and 95 to $110 \mathrm{~cm}$ sec dated (WIS-1081) to correlate pollen records from overlapping core segments. Pollen analysis of core is being completed by A Peters and T Webb III, Brown Univ. Depths are from top of core, water depth of coring site $8.5 \mathrm{~m}$. Coll and subm by A M Swain, Univ Wisconsin-Madison. Earlier date on sediment sample 603 to $612 \mathrm{~cm}$ deep from another core has been reported, WIS-373, 10,280 \pm 105 (R, 1970, v 12, p 341).

\section{WIS-1081. Stewart's Dark Lake site}

$1370 \pm 70$

Lake sediment 95 to $110 \mathrm{~cm}$ from sediment surface of 2nd core. Date will be used to estimate rates of sediment deposition and to correlate pollen records of the 2 cores.

\section{WIS-1078. Stewart's Dark Lake site}

$$
1770 \pm 70
$$

Lake sediment 100 to $110 \mathrm{~cm}$ from top of core.

WIS-1049. Stewart's Dark Lake site

$4185 \pm 70$

Gyttja, 2.95 to $3.05 \mathrm{~m} \mathrm{sec}$. Sample dates beginning of decline in percentages of oak and herb pollen and beginning of rise in percentages of birch and white-pine pollen.

WIS-1048. Stewart's Dark Lake site

$6350 \pm 70$

Gyttja, 4.60 to $4.70 \mathrm{~m} \mathrm{sec}$. Sample dates rise in oak pollen, decline in elm and hornbeam pollen, brief peak in birch pollen, and min in pine pollen.

\section{WIS-1015. Stewart's Dark Lake site}

$8640 \pm 90$

Dark brown lake sediment, 6.15 to $6.30 \mathrm{~m}$ sec of core. Sample marks 1st significant increase of white pine pollen percentages.

WIS-1017. Stewart's Dark Lake site

$$
10,140 \pm 105
$$

Laminated dark brown to black (with gray layers) lake sediment, 7.95 to $8.10 \mathrm{~m}$ sec. Sample dates decline of spruce pollen percentages.

WIS-1019. Stewart's Dark Lake site $10,570 \pm 110$

Clay with large plant fragments, 10.10 to $10.30 \mathrm{~m}$ sec. Sample gives min date for beginning of sedimentation in lake.

\section{Mount Yamaska site}

\section{E. Canada}

Core, $575 \mathrm{~cm}$, of lake sediment coll 1977 under direction of Pierre Richard, Univ Montreal, Canada, from small lake in Quebec near 
Granby $\left(45^{\circ} 27^{\prime} 30^{\prime \prime} \mathrm{N}, 72^{\circ} 52^{\prime} 20^{\prime \prime} \mathrm{W}\right)$. Subm by Thompson Webb, III. Samples dated to determine accurate sedimentation rate for computation of paleoisopols for Montreal region. Site is in strategic position to link results from St Lawrence valley and Lake St John's area.

WIS-979. Mount Yamaska site

Gyttja, 90 to $100 \mathrm{~cm}$ portion of core.

WIS-980. Mount Yamaska site

Gyttja, 190 to $200 \mathrm{~cm} \mathrm{sec}$ of core

WIS-981. Mount Yamaska site

Gyttja, 290 to $300 \mathrm{~cm}$ sec.

WIS-982. Mount Yamaska site

Gyttja, 390 to $400 \mathrm{~cm}$ sec.

WIS-983. Mount Yamaska site

Gyttja, 490 to $500 \mathrm{~cm}$ sec.

WIS-985. Mount Yamaska site

$$
\begin{array}{r}
1135 \pm \mathbf{6 0} \\
\delta^{13} C=-32.0 \% \\
\mathbf{2 8 5 0} \pm \mathbf{6 5} \\
\delta^{18} C=-32.0 \%
\end{array}
$$

$$
\begin{array}{r}
4510 \pm 75 \\
\delta^{13} C=-33.2 \%
\end{array}
$$

$$
\begin{array}{r}
\mathbf{7 2 6 5} \pm \mathbf{8 5} \\
\delta^{13} C=-33.3 \%
\end{array}
$$$$
\begin{array}{r}
\mathbf{9 8 4 0} \pm \mathbf{1 0 0} \\
\delta^{13} \mathrm{C}=-30.9 \% \text {. }
\end{array}
$$

$10,040 \pm 95$

$\delta^{13} C=-31.3 \%$ sediment.

Gyttja, 500 to $505 \mathrm{~cm} \mathrm{sec}$ of core, just above transition of mineral

\section{WIS-987. Mount Yamaska site}

$$
\begin{array}{r}
10,260 \pm 100 \\
\delta^{13} C=-29.0 \%
\end{array}
$$

Sandy gyttja, 505 to $515 \mathrm{~cm}$ sec, transition to inorganic sediments. Age should be min for deglaciation in area.

\section{Lake Marcotte site}

Core, $3.72 \mathrm{~m}$ coll July 1977 by Claude Labelle and Pierre Richard from Lake Marcotte, $15 \mathrm{~km}$ NW of Quebec City, Quebec $\left(47^{\circ} 04^{\prime} 40^{\prime \prime} \mathrm{N}\right.$, $\left.71^{\circ} 25^{\prime} 24^{\prime \prime} \mathrm{W}\right)$. Pollen analysis of core is underway. Subm by Thompson Webb, III.

WIS-1065. Lake Marcotte site

$$
\begin{array}{r}
\mathbf{8 9 4 0} \pm \mathbf{9 0} \\
\delta^{19} C=-32.9 \% \text { o }
\end{array}
$$

Gyttja from 270 to $280 \mathrm{~cm}$ sec of core. Sample dates max of Alnus crispus curve.

WIS-1066. Lake Marcotte site

$$
\begin{array}{r}
\mathbf{6 9 2 0} \pm \mathbf{8 5} \\
\delta^{1 s} C=-29.7 \% \text {. }
\end{array}
$$

Gyttja from 185 to $195 \mathrm{~cm}$ sec of core. Samples date max of Pinus strobus curve. 
WIS-1064. Lake Marcotte site

$$
\begin{array}{r}
\mathbf{4 0 4 0} \pm \mathbf{8 0} \\
\delta^{13} C=-31.1 \%
\end{array}
$$

Gyttja from 90 to $100 \mathrm{~cm} \mathrm{sec}$ of core. Sample dates beginning of Fagus curve.

\section{CLO site}

Core, $550 \mathrm{~cm}, 5 \mathrm{~cm}$ diam, coll 1978 by Pierre Richard from unnamed

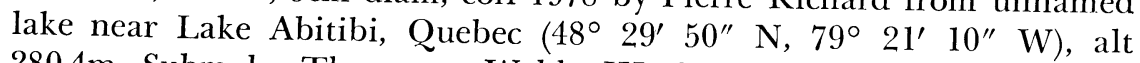
$280.4 \mathrm{~m}$. Subm by Thompson Webb, III. Samples dated to check sedimentation rate for paleoisopol determination. Core contained $360 \mathrm{~cm}$ of gyttja on glacial lake Barlow-Ojibway varved clay.

WIS-1061. CLO site

Gyttja and silty clay from 362 to $352 \mathrm{~cm}$ sec of core.

$$
\begin{array}{r}
\mathbf{8 3 1 0} \pm \mathbf{8 0} \\
\delta^{13} C=-33.2 \% \text { o }
\end{array}
$$

WIS-1060. CLO site

$$
\begin{array}{r}
\mathbf{5 2 1 0} \pm \mathbf{7 0} \\
\delta^{13} C=-28.9 \% \\
\mathbf{2 8 3 5} \pm \mathbf{7 5} \\
\delta^{13} C=-31.8 \% \circ
\end{array}
$$

Gyttja from 280 to $270 \mathrm{~cm} \mathrm{sec}$ of core.

WIS-1059. CLO site

Gyttja from 160 to $150 \mathrm{~cm}$ sec of core.

\section{Lake Yelle site}

Core, $500 \mathrm{~cm}, 5 \mathrm{~cm}$ diam, coll Feb 1978 by Pierre Richard from Lake Yelle, Abitibi, Ontario $\left(48^{\circ} 30^{\prime} 15^{\prime \prime} \mathrm{N}, 79^{\circ} 38^{\prime} 15^{\prime \prime} \mathrm{W}\right)$. Core included $385 \mathrm{~cm}$ gyttja on glacial lake Barlow-Ojibway clay. Palynologic study is underway. Core sampled to obtain sedimentation rate for paleoisopol determination.

WIS-1047. Lake Yelle site

$$
\begin{array}{r}
\mathbf{3 3 5 0} \pm \mathbf{7 0} \\
\delta^{13} C=33.3 \% 0
\end{array}
$$

Gyttja from 200 to $190 \mathrm{~cm} \mathrm{sec}$ of core.

\section{WIS-1054. Lake Yelle site}

Gyttja from 300 to $290 \mathrm{~cm}$ sec of core.

$$
5625 \pm 75
$$

WIS-1053. Lake Yelle site

$$
\mathbf{8 9 0 0} \pm 90
$$

Gyttja from 385 to $375 \mathrm{~cm}$ sec of core. Min age for $350.5 \mathrm{~m}$ alt of glacial lake Barlow-Ojibway. Pollen diagram shows open vegetation phase.

\section{Lake Romer site}

Core, 5m, of lake sediment on clay coll May 1978 by $\mathrm{P}$ Comtois from old channel of St Lawrence R, Lake Romer, Lanoraie, Berthier Co, Prov Quebec $\left(45^{\circ} 58^{\prime} \mathrm{N}, 73^{\circ} 20^{\prime} \mathrm{W}\right)$. Palynologic study and correlation of post-Champlainian core is underway. Subm by Pierre Richard.

\section{WIS-1058. Lake Romer site}

$$
\delta^{13} C=-31.0 \%
$$

Gyttja, 50 to $60 \mathrm{~cm} \mathrm{sec}$ of core. 
WIS-1057. Lake Romer site

Gyttja, 240 to $250 \mathrm{~cm} \mathrm{sec}$ of core.

WIS-1056. Lake Romer site

Gyttja, 310 to $320 \mathrm{~cm}$ sec of core.

WIS-1055. Lake Romer site

Gyttja, 430 to $440 \mathrm{~cm}$ sec of core.

$$
\begin{array}{r}
\mathbf{3 8 6 0} \pm \mathbf{7 0} \\
\delta^{13} C=-31.7 \% \text { o }
\end{array}
$$

$$
\begin{array}{r}
4520 \pm 80 \\
\delta^{13} C=-32.2 \% 0 \\
6920 \pm 80 \\
\delta^{1 s} C=-31.6 \% 0
\end{array}
$$

\section{La Tuque site}

Core, $496 \mathrm{~cm}$, coll 1977 under direction of Pierre Richard from small lake with $4.9 \mathrm{~m}$ water depth in La Tuque, Quebec $\left(\begin{array}{ll}47^{\circ} 28^{\prime} 29^{\prime \prime} \mathrm{N}, 72^{\circ} 45^{\prime} \\ \hline\end{array}\right.$ $55^{\prime \prime}$ W). Subm by Thompson Webb, III. Samples dated for determination of systematic sediment accumulation rate for precise determination of paleoisopols. Site is important because of strategic position to link results from St Lawrence valley and Lake St John area.

WIS-986. La Tuque site

$$
\begin{array}{r}
1840 \pm 60 \\
\delta^{13} C=-32.5 \% \text { o } \\
\mathbf{2 3 5 5} \pm \mathbf{5 5} \\
\delta^{13} C=-32.9 \% \text { o }
\end{array}
$$

Gyttja, 90 to $100 \mathrm{~cm} \mathrm{sec}$ of core.

WIS-989. La Tuque site

Gyttja, 190 to $200 \mathrm{~cm}$ sec of core.

\section{WIS-990. La Tuque site}

Gyttja, 290 to $300 \mathrm{~cm}$ sec of core.

$$
\begin{array}{r}
2675 \pm 60 \\
\delta^{13} C=-34.9 \% \text { o }
\end{array}
$$

\section{WIS-991. La Tuque site}

$$
\begin{array}{r}
7870 \pm \mathbf{8 5} \\
\delta^{13} C=-36.6 \% \text { o }
\end{array}
$$

Gyttja, 390 to $400 \mathrm{~cm} \mathrm{sec}$ of core.

\section{WIS-992. La Tuque site}

Sandy gyttja, 450 to $465 \mathrm{~cm}$ sec of core.

$$
\begin{array}{r}
8740 \pm 90 \\
\delta^{1 s} C=-34.4 \% o
\end{array}
$$

\section{WIS-1062. Lac aux Quenouilles}

$$
\begin{array}{r}
\mathbf{8 3 4 0} \pm \mathbf{9 0} \\
\delta^{13} C=-34.5 \% \text { o }
\end{array}
$$

Core, $945 \mathrm{~cm}$, $5 \mathrm{~cm}$ diam, coll Feb 1977 by Louise Savoie from small lake near Lac aux Quenouilles, $15 \mathrm{~km}$ NW of Sainte-Agathe $\left(46^{\circ} 10^{\prime} 20^{\prime \prime}\right.$ N, $74^{\circ} 23^{\prime} 45^{\prime \prime}$ W). Subm by Thompson Webb, III. Sample, organic lake mud from 825 to $835 \mathrm{~cm}$ sec of core, dates balsam fir phase in vegetation history of area.

WIS-1063. Lake Manitou site

$$
\begin{array}{r}
3330 \pm 70 \\
\delta^{1 s} C=-31.7 \% \text { o }
\end{array}
$$

Core, $855 \mathrm{~cm}$, $5 \mathrm{~cm}$ diam, coll Feb 1977 by Pierre Richard from small lake near Lake Manitou, $15 \mathrm{~km} \mathrm{~W}$ of Sainte-Agathe $\left(46^{\circ} 03^{\prime} 30^{\prime \prime} \mathrm{N}, 74^{\circ}\right.$ 
$28^{\prime} 00^{\prime \prime}$ W). Subm by Thompson Webb, III. Sample, gyttja from 285 to $300 \mathrm{~cm}$ sec of core, dated to check sedimentation rate for paleoisopol determination.

\section{Huatacocha Delta Site 2}

$$
\text { F. Peru }
$$

Peat coll July 1978 at peat-covered delta from glacial stream at NE edge of Lake Huatacocha Junin prov, Oyon map sheet, Peru $\left(18^{\circ} 47^{\prime} \mathrm{S}\right.$, $76^{\circ} 35^{\prime} \mathrm{W}$ ). Coll July 1978 and subm by $\mathrm{H}$ E Wright.

\section{WIS-1032. Huatacocha Delta Site 2}

$$
\begin{array}{r}
\mathbf{5 6 7 0} \pm \mathbf{8 0} \\
\delta^{1 s} C=-34.4 \%
\end{array}
$$

Moss peat 728 to $736 \mathrm{~cm}$ below surface. Sample dates inception of outwash supply to delta from glacial advance. Underlying sediments are lacustrine, overlying sediments are glacial silts up to level of $240 \mathrm{~cm}$.

\section{WIS-1031. Huatacocha Delta Site 2}

$$
\begin{array}{r}
1100 \pm 70 \\
\delta^{18} C=-26.6 \%
\end{array}
$$

Peat 225 to $235 \mathrm{~cm}$ below surface. Dates termination of outwash supply to delta from recent glacial advance and thus dates withdrawal of ice. Peat has subsequently grown over site.

\section{WIS-1068. Huatacocha Delta Site 2}

$$
\begin{array}{r}
10,050 \pm 100 \\
\delta^{I s} \mathrm{C}=-28.8 \% \text { o }
\end{array}
$$

Banded marl and organic clay 895 to $902 \mathrm{~cm}$ below delta surface. Sample dates beginning of lake sedimentation after retreat of ice from Huatacocha glacier.

\section{WIS-1070. Huatacocha Delta Site 2}

$$
\delta^{13} C=-27.2 \%
$$

Sample 118 to $123 \mathrm{~cm}$ below delta surface. Dates beginning of peat growth after withdrawal of local Huatacocha glacier when outwash ceased to flow to site.

\section{WIS-1067. Pistag Fan site}

$$
\delta^{13} \mathrm{C}=-25.6 \%
$$

Peat 25 to $32 \mathrm{~cm}$ below surface of peat-covered fan formed during retreat of Pistag glacier, Junin prov, Oyon map sheet, Peru $\left(10^{\circ} 47^{\prime} \mathrm{S}\right.$, $76^{\circ} 35^{\prime} \mathrm{W}$ ). Coll July 1978 and subm by $\mathrm{H}$ E Wright. Sample dates beginning of peat growth after withdrawal of local Pistag glacier when outwash ceased to flow to site.

\section{Lake Blatnica site}

$$
\text { G. Bulgaria }
$$

Core coll from Lake Blatnica, Duranculac, Black Sea coast of $\mathrm{N}$ Bulgaria $\left(43^{\circ} 43^{\prime} \mathrm{N}, 28^{\circ} 35^{\prime} \mathrm{E}\right)$ in 1976 by E Bozilova, Univ Sofia, Sofia, Bulgaria; subm by Thompson Webb, III. History of vegetation to be in paleoclimatic reconstruction of region and archaeol investigations of Lake Blatnica and island in lake. Pollen diagram of core has been prepared. 
WIS-1010. Lake Blatnica site

Phragmites peat from 146 to $150 \mathrm{~cm}$ sec of core.

WIS-1014. Lake Blatnica site

Phragmites peat from 182 to $185 \mathrm{~cm}$. sec of core.

\section{REFERENCES}

Bender, M M, Bryson, R A, and Baerreis, D A, 1970, University of Wisconsin radiocarbon dates VII: Radiocarbon, v 12, p 335-345.

1971, University of Wisconsin racliocarbon dates IX: Radiocarbon, v 13, p $475-486$.

p $611-623$

1975, University of Wisconsin radiocarbon dates XII: Radiocarbon, v 17, p $121-134$.

1976, University of Wisconsin radiocarbon dates XIII: Radiocarbon, v 18, p 125-139. p 127-137.

1977, University of Wisconsin radiocarbon dates XIV: Radiocarbon, v 19,

1979, University of Wisconsin radiocarbon dates XVI: Radiocarbon, v 21, p 120-130.

Friedman, R M and DeWitt, C B, 1978, Wetlands formation: spatial modeling of lakeedge wetlands development, in Waubesa conf on Wetlands proc, Inst Environmental Studies, Univ Wisconsin-Madison: Madison, Wisconsin, June 3-5, 1977.

Griffin, K O, 1977, Paleoecological aspects of the Red Lake Peatland, northern Minnesota: Can Jour Botany, v 55, p 172-192.

Hewes, G W, 1949, Burial mounds in the Baldhill area, Northern Dakota: Am Antiquity, $\mathrm{v} 14$, no. 4 , p $322-328$.

Johnson, W C, 1976, The impact of environmental change in fluvial systems, Kickapoo River, Wisconsin: PhD thesis, Univ Wisconsin-Madison.

1978, Intensified fluvial activity in response to Holocene climatic variations, in Am Quaternary Assoc 5th biennial mtg: Edmonton, Sept 1978 (abs).

Kivett, M F and Jensen, R, 1976, Archaeological investigations at the Crow Creek site (39BF11) Fort Randall Reservoir Area, South Dakota: Nebraska State Hist Soc Pub in Anthropology no. 7, xvi + 221 p, Lincoln, Nebraska.

Knox, J C, 1972, Valley alluviation in southwestern Wisconsin: Annals Assoc Am Geog, v 62, no. $3, \mathrm{p} 401-410$.

Neuman, R W, 1975, The Sonota complex and associated sites on the northern Great Plains: Nebraska State Hist Soc Pub in Anthropology No. 6, xv + 216 p, Lincoln, Nebraska.

Stuiver, M, Deevey, E S, Jr, and Rouse, I, 1963, Yale natural radiocarbon measurements VIII: Radiocarbon, v 5, p 312-342.

Stuiver, M, 1969, Yale natural radiocarbon measurements IX: Radiocarbon, v 11, p $545-658$. 